\title{
BRIDGING TOGETHER AUTHORITARIAN RIGHT-WING POLITICS AND NEOLIBERAL URBAN POLITICS: ISTANBUL'S BID FOR 2020 SUMMER OLYMPICS
}

\author{
YAVUZ YAVUZ ${ }^{1}$ \\ ${ }^{1}$ Ankara University, Department of Sociology, Dil ve Tarih-Coğrafya Fakültesi No:45/45-A 06100 \\ Sihhiye, Ankara, Turkey. ORCID: 0000-0002-7298-7604,Email: yavuzyavuz05@gmail.com
}

ABSTRACT: This study aims to analyse the political impact of sports mega-events through urban lenses. Sports mega-events often come along with drastic transformations in the built environment of the city where they are held. Contemporary urban impact of the sports mega-events, with the increased role rested by local and/or national governments on the private sector in the organization, is highly interconnected with the neoliberal measures of selling out the urban space, undertaken for hosting the event. In terms of the hosts, there is an increasing shift towards the countries where right-wing authoritarian parties are in power. I argue that the promises of these governments guaranteeing more swift urban transformations to meet the infrastructure requirements of hosting these events cause this shift and in turn, right-wing authoritarian governments use these events as platforms for disseminating their ideologies. This research aims to trace this trend, based on the example of İstanbul's failed bid to host the 2020 Summer Olympics and the neoliberal urban policies in Turkey under the Justice and Development Party (AKP). By using the city master plan presented during the bidding process and the statements made by AKP officials, I aim to demonstrate how hosting international sports events in Turkey is undertaken as part of a neoliberal urban policy and how this is incorporated into a wider conservative-Islamist political project by the AKP.

KEYWORDS: sports mega-events; urban entrepreneurialism; neoliberal urbanism; Istanbul; Olympic bids 


\section{INTRODUCTION}

Sorts mega-events are one of the most significant phenomena that extend national $\mathcal{S}$ and/or regional boundaries in the sense that they generate a significant amount of public interest and economic revenue. For this reason, hosting mega-events such as the Olympics and the FIFA World Cup attract local and national governments into filing bids. Sports mega-events lead to significant spatial changes in the cities where they are held, through urban development projects which are undertaken for meeting the requirements to host the event. Moreover, local and national governments increasingly utilize sports mega-events to transform cities in a manner that prioritizes attracting private investment. This way, hosting sports mega-events are harnessed into a "broader urban agenda" (Hiller 1999). While this enhances the role of the private sector in the organization of sports mega-events, local and national governments seek political gains out of hosting these events as well. Governments also use hosting sports mega-events as a way of disseminating dominant ideologies and influencing opinions held by -domestic or foreign- people and/or other governments (Black 2007). This research aims to look into the intersection of the economic and political aspects of hosting sports mega-events.

Under the Justice and Development Party (AKP) governments, Turkey has witnessed a surge in the number of international sports events being held on its soil, which brought about significant changes in numerous policy areas. Although these changes are related to every element intrinsic to sports mega-events such as athlete participation and media coverage, the most significant impact of the rising interest in hosting these events was on the urban landscape and the built environment of the cities where competitions are held. Numerous stadiums have been built in different cities, which are part of a wider boom in construction projects under the AKP. The new stadium projects are undertaken by private businesses that have close ties to the ruling party, as well as the Mass Housing Administration (TOKI), the government housing agency, which eventually obtained great power over the commodification of the urban space (McManus 2018:76). These newly built stadiums and sports venues made up an important part of the candidature files of the international sports events to which cities in Turkey put forward bids for hosting. A further aspect of the increased interest towards hosting international sports events and the ensuing urban transformation under the AKP government is the ideological dimension, which refers to the AKP using these events as a way of showcasing a novel, conservative-Islamist national identity. Urban development projects which are undertaken on the premises of hosting international sports events constitute a very important part in order to achieve this. Therefore, in this study, I aim to analyse the relationship between urban development projects and national identity formation in Turkey during the AKP era, within the scope of hosting international sports events.

For the purpose of this research, I examine the candidature of İstanbul for hosting the 2020 Summer Olympics. İstanbul's bid to host the 2020 Summer Olympics, albeit a failed one, was the biggest project of sports event hosting during the AKP era. İstanbul, by the merit of being the last capital city of the Ottoman Empire, holds a dis- 
tinctive place in the conservative-Islamist political mindset in Turkey, which makes a proposal to host the Olympic Games in the city a relevant subject matter for tracing the Islamist conception of a novel national identity in Turkey under the rule of the AKP. Furthermore, İstanbul is a significant city to observe the impact of the construction boom in Turkey under the AKP which transformed the urban spaces drastically. Lauermann (2016) contends that the failed Olympic bids play an integral role in shaping urban agendas. Furthermore, albeit a failed one, the 2020 Summer Olympics was the biggest bid for hosting an international sports event in Turkey during the AKP era, particularly in terms of urban planning. In this sense, I aim to locate İstanbul's failed bid for hosting the 2020 Summer Olympics in the AKP's Islamist ideology and the urban construction boom in Turkey.

In this research, I dominantly rely on the candidature file of İstanbul presented to the IOC. The urban development projects outlined in the bidbook are combined with the statements made by the then-Prime Minister Recep Tayyip Erdoğan and other AKP officials. In order to properly discuss these findings, I firstly begin with outlining the relationship between neoliberal urban planning and the Olympic Games, then, I move on to the conception of the city of İstanbul in the Turkish conservative-Islamist political mindset and how this is associated with the AKP's understanding of a novel national identity. Following this, I discuss how İstanbul's bid for hosting the 2020 Summer Olympics can be located at the intersection of these. My main argument is that right-wing authoritarian governments increasingly bid for hosting international sports events by promising swift urban transformation projects through neoliberal measures and use the events as a way of demonstrating a novel identity for their country in line with their ideologies. This research contributes to the existing literature on the urban impact of sports mega-events by combining economic and political dimensions at a time when more and more right-wing authoritarian regimes are hosting these events.

\section{URBAN POLITICS, IDEOLOGY AND THE OLYMPICS IN NEOLIBERAL ERA}

International sports events such as the Olympic Games have always come to carry significant spatial transformations. The venues where the competitions are held and the housing to accommodate delegations and other visitors as well as commercial areas are integrated into Master Plans of cities where the events are held. In the case of the Olympics, the scope of the urban transformation has changed from the first modern Olympics in 1896 to this day. Chalkley and Essex (1999) describe four phases in terms of analysing the urban impact of the Olympic Games over host cities. In the first phase which lasted from 1896 to 1904, the Olympics were small scale and had very little impact on the urban landscape of the host cities and the determination of host cities in this phase was largely symbolic. In the second phase from 1908 to 1932 , which was interrupted by the First World War, the Olympics grew larger, making it a necessity to build new facilities to meet the demands of hosting the event. This phase involved the construction of sporting sites for the very purpose of organizing Olympic sports competitions. In the third phase from 1936 to 1956, sporting facilities 
gained more importance as "flag-ship symbols" of host cities, despite their relatively modest influence over the urban space. The period between 1960 and 1996, marked the fourth phase which was the most politically turbulent era of Olympic history, in Cold War conditions. Hosting the Olympic Games grew larger in terms of impact over urban space in this phase. With the neoliberal transformation, the world started to go through in this period, the money revolving around the organization of the Olympic Games vastly grew. The role of the private sector increased while that of the public sector changed. This way the profit-making aspect of the Olympics came to the forefront of the organization and this led to the private companies taking over the process of staging the Games, with the enabling of the public sector.

Building on this four-step analysis, it is possible to speak about a fifth phase in the urban impact of hosting the Olympic Games as well. This fifth phase is characterized by the enhanced role of the urban neoliberal measures in the organizing of the Olympic Games and its influence over the urban space. Jessop (2002) contends that a neoliberal city encourages an economic and social restructuring driven by market interests. Neoliberalism as an economic project, in this sense, prioritizes the "liberalization and deregulation of economic transactions" across borders in a globalizing economic market. As a political project, neoliberalism foresees a retreat from state intervention of welfare systems and transforming it into one that gives way to a deregulated market structure. Furthermore, Peck, Theodore and Brenner (2009) hold that neoliberal programs are always accompanied by political-institutional contexts that facilitate the implementation of a deregulated market structure. At the urban level, this applies to urban and national governments actively engaging in promoting the urban space for attracting investments and acting as business partners.

A useful concept to understand the urban context of neoliberalism within the framework of hosting mega-events is urban entrepreneurialism, which refers to a form of urban governance that aims to sell-out the city in order to obtain an advantageous position in a structure of inter-urban competition (Harvey 1989; Leitner and Garner 1993; Swyngedouw 1992). Entrepreneurialism refers to a form of development of urban space directly related to productivity and investment and represents a shift from prioritizing providing public services to its population to incentivizing businesses to attract investment. Public-private partnerships are inherent to urban entrepreneurialism, as local governments allocate a significant amount of resources to attract external sources of investment. In the context of the Olympics, in order to better understand the scope of public-private partnerships, Giulianotti et al. (2015) propose the concept of 'New Right two-step'. The New Right two-step involves an initial public expenditure on sports venues, infrastructure developments and other urban projects. What follows is a neo-liberal process where sponsor corporations and construction companies enjoy a financial boom. The urban impact of this transformation becomes visible with the privatization of urban space which is reorganized in a manner that makes the built environment more appealing to the transnational capital flow and wealthier tourists as well as possible residents. Sports-related urban renewal projects often end up in a series of urban gentrifications ranging from housing to commercial areas and stadiums. In this sense, the urban transformation projects undertaken for 
hosting international sports events that last several weeks have longer enduring impacts on the cities where they are held. Boykoff (2016:157-160) calls this as 'celebration capitalism' denoting that a state of exception created for temporary time spans (namely, the duration of the event) takes permanent effect and it is mostly characterized by public-private partnerships in which most of the expenses are made by the public sector whereas the sponsorship and investment deal direct most of the revenues towards the corporations. As Horne and Manzenreiter (2006) contend, the estimations about the benefits of hosting such events rarely live up to the promise. Under these circumstances, one of the most important factors that make bidding for hosting international sports events is the expected political outcomes.

The neoliberal transformation of urban space has political and cultural/ideological dimensions as well. A growing body of research forms a link between the neoliberal economy and the rise of authoritarian politics (Brown 2003; Bruff 2014). Accordingly, Peck, Theodore and Brenner (2009) argue that neoliberalism exists in a 'parasitical relation' with different state and social formations including neoconservatism and authoritarianism, which refers to 'national projects of institutional restructuring' accompanying the neoliberal transformation. In the context of international sports events, the urban transformation projects that are implemented for hosting can be used to transmit a certain message about the host which is directed at the international community and the domestic population alike. As Black (2007) underlines, a narrative that outlines why the candidate city is suitable for hosting the Olympic Games is inevitably integral to the bidding process, due to the cosmopolitan self-image of the international sports events. The post-Second World War trend of awarding the Olympics to the cities in former Axis Powers such as 1960 Roma, 1964 Tokyo and 1972 Munich is significant in terms of transmitting a message of change and restoring these countries' places in the international community. Furthermore, hosting international sports events is framed as a noble endeavour of universalism in order to mobilize public enthusiasm and mass support for the bidding process. However, the scope of the political aspect of hosting international sports events reaches far beyond these political narratives.

Numerous researches underline the political dimension of hosting sports mega-events in a wide range of terms including nationalist politics, media coverage and international relations (Tomlinson \& Young 2006; Grix \& Lee 2013; Vincent et. al. 2018). International sports events, such as the Olympic Games have always been an important stage for displaying and consolidating nationhood. The competitive element in these events makes it easier for the perceived national group to imagine nationhood and rally around the national identity. In this sense, sports mega-events have always been instrumental for nationalist politics. According to Allison \& Monnington (2002), national pride can be derived from sports in two ways, which are being recognized by taking part in sports events or displaying power through hosting the events or winning honours in them. There are a number of contemporary studies which demonstrate and conceptualize how hosting these events serves to the purpose of signalling nationhood. For instance, Skey (2006) proposes the concept of 'ecstatic nationalism' in order to explain the impact of special events that take place over 
limited periods of time. Ecstatic nationalism denotes the performative outbursts of nationalist aspirations during special events. Such events as the Olympic Games, give way to different articulations regarding discourses of nationhood and hosting these events hinder daily life to the extent that the narrative revolving around the national identity and its perceptions become more visible than before, during the period when the event is held.

However, differing from Skey's analysis which focuses on discourses and narratives around national identity through media coverage or other overt displays of nationalism, this study focuses on the relationship between international sports events and national identity through the lenses of the built environment. This makes it easier to observe the enduring outcomes of the spatial transformation related to the event and to trace the relationship between neoliberal urban transformation and nationalist politics. In the case of İstanbul's bid for hosting the 2020 Summer Olympics, these are presumed outcomes as the bid eventually failed. Lauermann (2016) holds that temporary projects of hosting temporary one-off events have durable impacts on the urban space and therefore bidding for organizing these events allow implementing long-term development plans hence, the temporariness become one of the required elements of 'durable neoliberalisation'. Moreover, unsuccessful bids contribute to and shape the long-term urban agendas to an extent that cannot be overlooked. This is a result of the financial and political guarantees required for filing a bid, which brings together political and corporate actors in public-private partnerships. Furthermore, bids, successful or not, help the governments put forward an identity of their country on an international platform. For these reasons, researches on unsuccessful bids are relevant to examine the economic and political impacts of hosting international sports events.

Sports mega-event hosting is increasingly utilized by authoritarian regimes as platform for legitimizing their policies both domestically and internationally and disseminating dominant ideas and views. These regimes take advantage of the increasing expenses of the Games and related increasing reluctance to host them through excessive financial investments and mega construction projects and with the promise of swift decision-making, by the help of suppression of opposition in authoritarian rules. Awarding of 2014 Winter Olympics to Sochi in Russia despite the global outcry due to the anti-LGBTI+ laws in Russia and Sochi being the site of Circassian genocide in the $19^{\text {th }}$ century can be an example of this (Boykoff 2016:200-201). Another example can be Qatar, which hosted the World Athletics Championships in 2019 and is set to host the FIFA Men's World Cup in 2022. As mega stadium constructions are underway in Qatar, human rights organizations such as Amnesty International (2019) decry the exploitation of workers, most of them migrants, working in unsafe and precarious conditions. AKP's policies of hosting international sports events in Turkey can be evaluated in this category as well, as a way of drawing sports events through promises of vast financial investments and using them as platforms of implementing and transmitting political views, as well as seeking legitimacy in the international arena. In order to analyse İstanbul's bid to host the 2020 Summer Olympics, it would be accurate to first contextualize the bidding process by reflecting on the construction boom in Turkey 
under the AKP governments, the conception of İstanbul in the conservative-Islamist political mindset and the impact of these over sports.

\section{TRACING THE POLITICS OF TURKEY'S CONSTRUCTION BOOM IN ISTANBUL}

Political action takes place in a space which almost all the time carries a symbolic value. Spaces are created and invented therefore it is important to examine the meanings they carry for the actors that operate within them (Edelman 1967:95-96; Lefebvre 1991). İstanbul constitutes an important place as a result of its symbolically loaded geographical location, as a site for contestation of inherent opposites such as East and West, local and global (Keyder, 2000:17). Moreover, as the last capital of the Ottoman Empire, İstanbul is the main place for the conservative-Islamist politics represented by the AKP which spatially characterizes the narrative of a novel national identity (Tokdoğan 2018:168). As Recep Tayyip Erdoğan, who went on to be the chair of the AKP, former Prime Minister and the President of Turkey, first came under the political spotlight at a national scale as the mayor of İstanbul, the city holds a distinct place in the AKP's political mindset. Furthermore, this provides a useful starting point for tracing the expansion of the construction sector in Turkey under the tenure of the AKP governments.

Particularly following the global economic crisis in 2008, the construction sector in Turkey witnessed an immense growth. One of the central roles in this growth belongs to the Mass Housing Development Administration (TOKİ). TOKİ was founded in the 1980s in order to provide loans to small contractors and people who wanted to buy a house, however through a series of legal amendments during the first years of the AKP government between 2002 and 2008, it was surrounded by immense authorities ranging from authorizing the privatizations of public lands to executing urban transformation projects (Balaban 2016:27). Furthermore, the Ministry of Environment and Urbanism was handed immense authorities as well, in order to realize public-private partnerships for mega urban projects such as a third bridge over the Bosphorus Strait or the third airport in İstanbul. The construction of these mega projects is often undertaken by pro-government conglomerates whose business portfolio extend to many fields including the media, through acquisitions of pro-government media groups (McManus 2018:77). In this sense, it can be inferred that the commodification of urban space is used as a driving force to initiate production and consumption in a number of other areas. Furthermore, for the conservative-Islamist politics in Turkey, construction and altering the urban space have long come to be seen as the most explicit way of establishing hegemony and generating consent (Çavuşoğlu \& Strutz 2014; Yeşilbağ 2016). This puts a particular emphasis on the grandeur of the urban development projects both in physical and symbolic terms (Bora 2016:13). İstanbul, as the last capital of the Ottoman Empire, has been a crucial site in terms of the relationship between urban space and establishing political consent for the conservative-Islamist ideology in Turkey.

The image of İstanbul is a crucial crossing point between conservative Islamism and nationalism in Turkey. İstanbul, according to Bora (2000:62), represents both the 
Ottoman hegemony and the rule of Islamic law in the Islamist political mindset. In other words, İstanbul represents the geographical hub of the conservative-nationalist political agenda, by references to its history as the capital of the Ottoman Empire, hence the final place where the Caliphate resided. Combined with the constant references to the multicultural demography of the city, particularly through the substantial non-Muslim population in the past, this discourse produces and reproduces the Ottoman imagination of Islamist politics underlining the unequal cohabitation as proof of the Ottoman hegemony and the jurisdiction of Islamic rule. This leads to a neo-Ottoman nostalgia towards İstanbul in the political mindset of the AKP, pointing towards a lively 'promise of return' to the city's past status in the Ottoman era, which is later transferred to Ankara as one of the earliest moves of the Republican period (Tokdoğan 2018:169). A link can be traced between the symbolic loss of power experienced by İstanbul and the concept of a revanchist city, which implies a political strategy that stems from resentment, and is enabled for the reestablishment of an idealized golden age and a supposedly lost old order (Smith 1996). In the case of İstanbul, a motive of nostalgia is manifested as labelling the city as the site for the embodiment of a novel national identity by the AKP. The steps taken in this direction can explicitly be exemplified with the conversion of the Hagia Sophia from a museum into a mosque, restoring its status during the Ottoman era. ${ }^{1}$ This can be traced back to the days when Recep Tayyip Erdoğan, the current President of Turkey and the leader of the AKP became the mayor of İstanbul in 1994.

During the local election campaign of 1994, while most of the other parties' candidates focused on İstanbul as a 'global city', Erdoğan's mayoral campaign focused on the shanty towns and their residents (Bora 2000:67). While votes from these regions of the city became influential in the election of Erdoğan, they also provided crucial public spaces for the mobilization of conservative-Islamist ideology. After the election, the networks in these regions of İstanbul were translated into 'welfare systems' involving Islamist organizations and Welfare Party's municipalities, which were officialized and integrated to central state structure after 2002, when the AKP first became government (Batuman 2019:95). Başakşehir region of İstanbul is emblematic of the urban transformation policies of Islamist politics in the sense that it corresponds to the emergence of an urban, middle-class conservative base, through the construction of gated communities. Başakşehir was a project realized by the KİPTAŞ, a housing company run by the municipality and the role of KIPTAŞ was extended to the TOKİ (Mass Housing Administration), the public housing agency, at a countrywide scale after the AKP came to power in 2002 (Çavdar 2016). When the AKP came to power in 2002, the urban policies did not remain limited to housing and gradually expanded to include constructions and transformations of public spaces. Large scale urban development projects transform the built environment in a way that leads to new forms of socialization. One of these mega-projects undertaken by public-private partnerships is the construction of a massive mosque to the Çamlica hill overlooking

\footnotetext{
${ }^{1}$ Hurriyet Daily News. 10 July 2020. "Hagia Sophia converted into mosque as Erdoğan signs decree.” Retrieved 25 July, 2020 (https://www.hurriyetdailynews.com/hagia-sophia-converted-into-mosqueas-erdogan-signs-decree-156455).
} 
İstanbul. Çamlıca mosque, which in Erdoğan's words “can be seen from everywhere in the city" is designed in a neo-Ottoman style and its geographical domination over İstanbul's skyline is an example of the ideological designing of urban space through mega projects (Batuman 2019:58). These construction projects do not only reflect the image of a return to the Ottoman heritage and the reclaiming of urban space in the former capital of the Empire, but they also serve to the imagining of a novel social organization. Mosques, as places where people gather, socialize and partake in a collective ritual, are ideal places for communicating political messages and rallying people around those messages. Stadiums and other sports venues have the potential to serve to similar ends, which makes them relevant as subjects of analysis.

Although references to the Ottoman past are very common in the politics of Turkey, its adoption by the AKP deserves particular attention as it is integrated as part of the imagining of a novel national identity. In the case of the adoption of Ottoman references by the conservative-Islamist politics in Turkey, restoration of this part of the past carries the aim of making the Ottoman a formative part of the national identity (Tokdoğan 2018: 84). Therefore, a specific focus on this policy is required to better comprehend the contested nature of nationhood in Turkey under the rule of the AKP governments. Moreover, İstanbul emerges as the spatial epicentre of this reimagining of the national identity and restoring its image as the historic capital of the Ottoman Empire plays a critical role along the way (Tokdoğan 2018: 90). In this sense, it is important to analyse the formation and imagining of a novel national identity through a spatial transformation that creates collectivities.

\section{CONSTRUCTION, POLITICAL HEGEMONY AND SPORTS IN ISTANBUL}

From 2007 to 2015, Turkey has built more stadiums than any other UEFA member country, including Russia which was set to host the FIFA World Cup in 2018. A significant number of the eighteen new grounds of this period were built in conservative-nationalist hubs like Konya, Trabzon and Sakarya. Most of these cities were not in need of stadiums big as the ones that are built, such as Konya, where the newly built stadium's capacity of 42.000 was solely chosen as a reference to the city's plate number, 42. A common theme for these cities where new stadiums are built is that the former grounds had been built at the city centre as part of the Republican project up until the $1950 \mathrm{~s}$, and the replacements are moved to the outskirts. Therefore, these gentrified stadiums appeal more to those who have the time and money to spare to make the long journey to the venues (McManus 2018:75-76). New football grounds were built in İstanbul as well, one belonging to the football club of Başakşehir, the aforementioned site of urban transformation in İstanbul, leading to the formation of a conservative middle class. The construction of the stadium was undertaken by Kalyon group, a conglomerate with close ties to the AKP that owns a large pro-government media group and undertakes other mega construction projects such as the new airport of İstanbul. ${ }^{2}$

However, hosting sports mega-events is a different agenda for İstanbul's urban

\footnotetext{
${ }^{2}$ BirGün. 24 July 2020. "Yeşil Sahalarda Yeşil Sermaye: BAŞAKŞEHİR A.Ş.” Retrieved 25 July, 2020 (https://www.birgun.net/haber/yesil-sahalarda-yesil-sermaye-basaksehir-a-s-309464).
} 
politics. İstanbul, in fact, enjoyed the position of being an international power hub extensively, and showcasing through mega-events have come to be an important part of it. Its geographical as well as a symbolic political value of being in the middle of the continents of Europe and Asia, became Turkey's main poster at the international stage, despite losing its capital status with the transition from the Ottoman Empire to the Republic of Turkey. In 1936, Henri Prost, a French urbanist was invited to Turkey to draw up a master plan for an Olympics and World's Fair to be held in İstanbul (Bilsel \& Zelef 2011). However, aspirations for hosting the Olympic Games in Turkey are far more related to the global neoliberal trend. Despite Prost's master plan never came into effect due to the Second World War, at the same periodical time with the rise in entrepreneurialism trend in urban governance discussed above, hosting the Olympics came back in the political agenda in Turkey in the 1980s. A municipal action programme was put together to host the Games in 1988 (Bilsel and Zelef 2011). İstanbul's first bid to host Olympic Games came with legislation enacted in the parliament called Law on Olympic Games to be Organized in the City of İstanbul (Turkish Law, No: 3796), in 1992. Although all five of İstanbul's Olympic bids failed, the willingness for hosting the Games had important impacts in terms of urban development. For instance, with the purpose of hosting the 2004 Summer Olympic Games, Ataturk Olympic Stadium in İstanbul was inaugurated, which is perhaps the only stadium with the word 'Olympic' in its name to never host the Olympic Games. However, Turkey hosted numerous sports events during the period of the AKP governments, including those in İstanbul such as the famous UEFA Men's Champions League Final in 2005, several group round matches and final round matches of FIBA World Championships for Women in 2014 and the knock-out phase of Eurobasket 2017.

Hosting these events are also critical to evaluate the contested nature of the national identity within the context of sports, in terms of the AKP's political project of imagining a novel image of Turkey and how it interacts with the opposition. For instance, the Islamic Solidarity Games of 2021 set to take place in İstanbul ${ }^{3}$ was moved to the conservative power hub of Konya, ${ }^{4}$ where nationalist-Islamist politics have historically held a stronghold. This came right after the election of an opposition candidate as the mayor of İstanbul in the municipal elections of 2019. This demonstrates the role that hosting international sports events plays in the policy of the AKP, as the party relies on the financial ties revolving around the municipal administrations for the organizing of the event. While all these served to the establishment of an increasingly privatized urban economic regime and the instituting of a novel identity of ' $\mathrm{New}$ Turkey', branded by the AKP, through a conservative-Islamist political view, candidacy for hosting the 2020 Summer Olympics was the biggest project of them all.

\footnotetext{
${ }^{3}$ Hürriyet. 06 April 2017. “İslami Dayanışma Oyunları 2021 yılında İstanbul'da düzenlenecek.” Retrieved 11 June, 2020 (https://www.hurriyet.com.tr/sporarena/islami-dayanisma-oyunlari-2021-yilinda-istanbulda-duzenlenecek-40418879).

${ }^{4}$ Yeni Şafak. 20 December 2019. “5. İslami Dayanışma Oyunları 2021'de Konya'da.” Retrieved 11 June, 2020 (https://www.yenisafak.com/gundem/5islami-dayanisma-oyunlari-2021de-konyada-3518862).
} 


\section{ISTANBUL'S BID FOR HOSTING THE 2020 SUMMER OLYMPICS}

Istanbul filed its candidature to host the Summer Olympics five times and the final bid was for the 2020 Summer Olympics. İstanbul's bidding process to host the 2020 Summer Olympics began in 2011 and ended with the vote in September 2013. İstanbul made it to the second round of voting, while no candidate city won half of the votes required to win the Games in the first round and Madrid was eliminated in the first round with a run-off vote against İstanbul. In the second round of voting, Tokyo gathered 60 votes against İstanbul's 36 and won the race to host the XXXII. Olympic Games. ${ }^{.}$The candidacy was a major government project as the category of 'Government and public support' received the highest points $(8 / 9)^{6}$ from the International Olympic Committee (IOC) and the bidding process was launched by the then-Prime Minister Recep Tayyip Erdoğan, on 13 August 2011. ${ }^{7}$ Calling the prospect of hosting the Olympics in İstanbul a "belated rendez-vous”, Erdoğan stated that, “İstanbul is not only a city that brings together three continents for centuries, but it is also a monumental capital where different civilizations, faiths and cultures live together fraternally". The main motto of the candidacy was 'Bridge Together', and relatedly most visible cultural references made while making the case for the hosting bid of İstanbul for the 2020 Summer Olympics were those that entail the city's heritage from the Ottoman era and the geographical positioning of the Bosphorus strait between Europe and Asia. As Erdoğan stated in the launch of the bidding campaign, "(...) one of the most remarkable chapters of Olympic history will be written in this city [İstanbul] of unique beauty, bringing together three continents”. Erdoğan made remarks about the ongoing financial crisis as well, citing growth rates as a solidifying factor for İstanbul's bid. This is no surprise, as Turkey's emergence with higher growth rates following the 2008 financial crisis is mostly a result of the enlargement of the construction sector with foreign debt (Yeşilbağ 2016).

İstanbul's candidacy for hosting the Games demonstrates a clear example of neoliberal urban politics and public-private partnership. Seven grand corporations, including Digiturk, Doğuş Holding, Koç Holding, Sabancı Holding, Turkcell, Turkish Airlines and Ulker have signed a sponsorship contract with Turkey's National Olympic Committee for its bid to host the 2020 Summer Olympics, ${ }^{8}$ while Turkey's public housing agency TOKİ (Public Housing Development Administration) in its presentation to IOC's Evaluation Committee, outlined plans for the construction of a new urban settlement which would cover an area of $420 \mathrm{~km}^{2}$, which is more than $1 / 12$ of the entire city. ${ }^{9}$ The overall cost of construction projects outlined by TOKI was estimated

\footnotetext{
${ }^{5}$ BBC. 07 September 2013. "Olympics 2020: Tokyo wins race to host Games.” Retrieved 10 June, 2020 (https://www.bbc.com/sport/olympics/24002795).

${ }^{6}$ International Olympic Committee (2012) Games Of The XXXII Olympiad 2020 Working Group Report. IOC report. 05 April Lausanne: IOC, p. 26.

${ }^{7}$ Habertürk. 13 August 2011. “2020 Olimpiyatları'na adayı!! Retrieved 09 June, 2020 (https://www. haberturk.com/spor/olimpiyat/haber/658653-2020-olimpiyatlarina-adayiz).

${ }^{8}$ Hürriyet. 21 January 2013. “2020 Olimpiyatları için dev ortaklık.” Retrieved 09 June, 2019 (http://www. hurriyet.com.tr/2020-olimpiyatlari-icin-dev-ortaklik-22408288).

${ }^{9}$ BBC Türkçe. 03 April 2013. “İstanbul 2020: Belki şehre olimpiyat gelir.” Retrieved 09 June, 2019 (https://www.bbc.com/turkce/spor/2013/04/130403_cuneyt_olimpiyat).
} 
approximately as $\$ 25$ million. ${ }^{10}$

İstanbul's bid shows characteristics of creating a state of exception as the government support behind the candidacy relies mostly on the administrative capacity of preparing legal and executive frameworks for the organizational adjustments rapidly. During the launch of the candidacy, Erdoğan promised the enactment of a new law for İstanbul, "[Our government] will make the necessary authorizations, through a special law, in order to immediately actualize the investments needed for the organization". ${ }^{11}$ Furthermore, tax exemptions and other legislative changes were also promised. ${ }^{12} \mathrm{~A}$ further example of the state of exception through the government's hand in the case of a potential Olympic Games in Turkey was in fact experienced in 2013, prior to the vote to determine the host city of 2020 Summer Olympics, when Turkey hosted the XVII. Mediterranean Games. The 2013 Mediterranean Games were initially awarded to the combined bid of Greek cities, Volos and Larisa, however they were stripped of hosting rights due to the financial crisis in Greece and Turkey's southern city of Mersin won an online vote in 2011 to host the Games. ${ }^{13}$ The seventeenth Mediterranean Games were held in June 2013, right in the middle of one of the largest protests to ever take place in Turkey, which started in İstanbul as the city witnessed the biggest urban social movement in its recent history, against the demolishment of Gezi Park. Although the protests were hardly mentioned by government officials or the IOC in the remaining three months of the bidding process, the Mediterranean Games hosted by Mersin during the summer of 2013 witnessed the ruling AKP's provincial branches purchasing and distributing tickets to their members en masse, for the opening ceremony, instead of regular sales, ${ }^{14}$ in an attempt to suppress any potential anti-government protest that might erupt in the stands during the ceremony.

İstanbul's Olympic Games Master plan is comprised of four zones of sites and venues that include seven clusters. Three of the four zones are located at the European side of the city, except for the Bosphorus Zone. Out of the 37 (3 of them are football stadia to be built in Ankara, Antalya and Bursa), structures listed in these seven clusters (including stand-alone venues), only 11 were presently available at the time of the bidding process. In this sense, it would not be far-fetched to argue that such a potential Olympic urban design of İstanbul would rely on the eerily growing construction sector. There are also several promises in the candidature file that do not quite match reality and one of them is regarding transportation. While the bid promised that " $100 \%$ of athletes will be within 35 minutes of competition venues and the average athlete trip is 12 minutes", ${ }^{15}$ it would be a difficult task for the already struggling transportation

\footnotetext{
${ }^{10}$ Hürriyet. 25 March 2013. “2020 için TOKİye inanılmaz bütçe.” Retrieved 05 June, 2019 (http://www. hurriyet.com.tr/2020-icin-tokiye-inanilmaz-butce-22892697).

${ }^{11} 2020$ Olimpiyatlarına Adayı!

12 İstanbul 2020 bid book, Vol. I, pp. 83, 93.

${ }^{13}$ CNN Türk. 23 February 2011. “2013 Akdeniz Oyunları Mersin’de.” Retrieved 09 June, 2020 (https:// www.cnnturk.com/2011/turkiye/02/23/2013.akdeniz.oyunlari.mersinde/607937.0/index.html).

${ }^{14}$ Hürriyet. 20 June 2013. “Akdeniz Oyunları'nda ‘bilet krizi'.” Retrieved 09 June, 2020 (http://www.hurriyet.com.tr/ekonomi/akdeniz-oyunlarinda-bilet-krizi-23549027).

${ }^{15}$ İstanbul 2020 bid book, Vol. II, p. 23.
} 
structure, which received one of the lowest points $(5 / 7)^{16}$ from the IOC, with the city's estimated population of 16 million, and the Olympic visitors. Almost entire operations regarding the construction and maintenance of the venues are rested on TOKI's Game Directorate ${ }^{17}$, which "benefits from a direct reporting relationship to the Prime Ministry and a high degree of autonomy to deliver its mandate". ${ }^{18}$ Furthermore, TOKİ is surrounded by expanded authorities of land acquisition and expropriation ${ }^{19}$ which lead some international watchdogs to voice concerns of forced displacement. ${ }^{20}$ All in all, these reflect the extensive role allocated to TOKİ in terms of urban design during the era of the AKP governments. This is a clear example of urban entrepreneurialism in AKP-era Turkey, as in a joint letter co-signed by five officials including the thenPrime Minister Recep Tayyip Erdoğan and the then-mayor of İstanbul Kadir Topbaş, "the entrepreneurial spirit of new Turkey" ${ }^{21}$ is mentioned. Moreover, TOKİ promised 18 new stadium constructions in 16 different cities during the bidding process. ${ }^{22}$ These demonstrate the neoliberal processes that are at play in the planned transformation of the built environment during İstanbul's bid for hosting the 2020 Summer Olympics.

According to Batuman (2019:28), the constructions oversaw by TOKI also lead to the attribution of an Islamic character to the urban spaces and this can be observed in İstanbul's bid for hosting the 2020 Olympics as well. For instance, despite the fact that all opening and closing ceremonies of the Summer Olympics are held in Olympic Stadiums of the cities where the Games are held, in İstanbul's bid, a temporary venue called the Bosphorus Stadium was planned to be built near the historic Haydarpaşa Train Station to host the ceremonies and several other events. This 70,000-seat stadium would cost more than $\$ 474,000^{23}$ and was planned to be dismantled after the Games end. Placed beside the Bosphorus strait between the continents of Europe and Asia, a significant aspect of this stadium is that, if realized, it would have a clear vision of the Topkapı Palace, the main court of the ruling dynasty of the Ottoman Empire in İstanbul for nearly 400 years. Although the Topkapı Palace is historically a significant part of the city's landscape, the fact that the opening and closing ceremonies are not held in Atatürk Olympic Stadium, which was specifically built for the purpose of hosting the Olympics implies a wider political symbolism.

The most visible cultural references in the hosting bid of İstanbul for the 2020 Summer Olympics are those that entail the city's heritage from the Ottoman era and the geographical positioning of the Bosphorus strait between Europe and Asia. In the presentation before the $125^{\text {th }}$ IOC Session in Buenos Aires, then-Prime Minister Recep Tayyip Erdoğan states that İstanbul's bid brings together past, present and future, as

\footnotetext{
${ }^{16} 2020$ Working Group Report, p. 22.

17 İstanbul 2020 bid book, Vol. II, p. 37

18 İstanbul 2020 bid book, Vol. II, p. 53.

${ }^{19}$ İstanbul 2020 bid book, Vol. II, p. 57.

${ }^{20}$ Bianet. 21 August 2013. “'Zorla Tahliyeler Olimpiyatın Kirli Yüzü’.” Retrieved 10 June, 2020 (https:// bianet.org/biamag/toplum/149305-zorla-tahliyeler-olimpiyatin-kirli-yuzu).

${ }^{21}$ İstanbul 2020 bid book, Vol. I, p. 11.

${ }^{22}$ Yeni Şafak. 11 August, 2013. "16 ile 18 stadyum daha.” Retrieved 14 June 2021 (https://www.yenisafak. com/politika/16-ile-18-stadyum-daha!-552794).

${ }^{23}$ İstanbul 2020 bid book, Vol. II, p. 39.
} 
well as claiming that awarding the Games to a Muslim country would send a message to the broader region. ${ }^{24} \mathrm{~A}$ further indication to this can be traced in the candidacy file of İstanbul, which defines it as, "A vibrant mega-city spanning two continents, more than three civilisations and eight millennia, (...) the world's capital of creativity, diversity and inclusiveness." ${ }^{25}$ Other examples of the references for the Islamic religious character include the promotional candidate video which begins with the image of a man praying before a mosque. ${ }^{26}$ In the same video, mosque minarets are a recurring image while the only reference to multicultural demography is the image of mosaics in the Hagia Sophia. Furthermore, according to the candidature file, the aspiration to host the Olympic Games was set to deliver "national pride outcomes for the nation which would last for generations." ${ }^{27}$ There are constant references to the prospect of hosting the Olympics in a 'secular Muslim society'. In the section on the motivation for hosting the Games, while stating that "İstanbul 2020 offers an opportunity for the first ever secular Muslim democracy to host the Games and the first ever city to stage the event on two continents simultaneously" ${ }^{28}$, the state's relationship with religious identity is listed ahead of its geographical significance with regards to the Bosphorus strait. Although these may be analysed as a way of attracting international voters to opt for İstanbul as the host of the 2020 Summer Olympics, the statements in the pro-government media on the candidacy provide a clearer picture of such emphases. For instance, in a pro-government newspaper, Star, a columnist contended that the reason why İstanbul lost the vote is Islamophobia. ${ }^{29}$ This indicates an imagination of a novel identity which is based on religion, as İstanbul's bid for hosting the Games is associated with a Muslim-self and choosing Tokyo over is labelled as a form of enmity. In other words, opposition to the candidacy, which is equated with the novel identity and opposition to it is understood as a threat. This perception is a threat is perhaps best manifested by another pro-government newspaper, Türkiye, which labels an online petition following the Gezi Park protests, against İstanbul's bid for hosting the 2020 Summer Olympics as treason. ${ }^{30}$ This way, it is possible to trace both faces of national identity formation, external and internal. Externally this process is defined by identifying the opponents of İstanbul's bid as Islamophobes whereas internally they are labelled as traitors, which manifests the instrumentalization of the bidding process for a wider political purpose. In this sense, İstanbul's failed bid for hosting the 2020 Summer Olympics is the concretization of a more comprehensive political pro-

\footnotetext{
${ }^{24}$ Olympic. 2013. “Presentation by Istanbul, Turkey.” Retrieved 10 June, 2020 (https://www.youtube. com/watch? $\mathrm{v}=\mathrm{I} 7 \mathrm{dV} 17 \mathrm{zqJ} 6 \mathrm{k} \& \mathrm{t}=21 \mathrm{~s})$.

25 İstanbul 2020 bid book, Vol. I, p. İ.

${ }^{26}$ Olympic. 2013. 2020 "Olympics - Istanbul, Tokyo and Madrid Promotional Candidate Videos." Retrieved 10 June, 2020 (https://www.youtube.com/watch?v=HI3ErDjr4BY).

${ }^{27}$ İstanbul 2020 bid book, Vol. II, p. 11.

${ }^{28}$ İstanbul 2020 bid book, Vol. I, p. 21.

${ }^{29}$ Star. 09 September 2013. “Ezikliğin son noktası: Ooh İstanbul kaybetti.” Retrieved 14 June 2021 (https://www.star.com.tr/yazar/ezikligin-son-noktasi-ooh-istanbul-kaybetti-yazi-787558/?fbclid=IwAR3c_Nle-mBIFxJruCJ2xcoNmQB_jBM1whWAE8anh2eYu1C2RHPffXff-xk).

${ }^{30}$ Türkiye. 14 June 2013. “İşte Gezi mektubu, her satırı ihanet.” Retrieved 14 June, 2021 (https://www. turkiyegazetesi.com.tr/gundem/45141.aspx).
} 
ject of combining neoliberal politics with the promotion of an Islamist reimagining of national identity.

\section{CONCLUSION}

In this paper, I argue that hosting international sports events constitute an important element of the AKP's urban politics that reflect the neoliberal turn the urban governments took with urban entrepreneurialism and public-private partnerships. Furthermore, I argue that the international sports events held in Turkey during the tenure of the AKP governments serve to a wider political project, which is reflecting the Islamist political ideology through signifiers and references such as those to the Ottoman past. İstanbul is an ideal case study to demonstrate this in the sense that it used to be the capital of the Ottoman Empire, as well as an important hub for the neoliberal urban activities of right-wing governments at local and national levels, through enabling enlarged construction sectors. Hosting the Olympic Games is one of the biggest projects in this regard and that is the reason I chose İstanbul's bid for the 2020 Summer Olympics as a topic of research.

Conducting analysis on an event that did not take place is difficult, however, İstanbul's candidacy for the 2020 Olympic Games provides sufficient data for analysis as it made it to the final round of the bidding process. This way, although failed, İstanbul's bid presents an example of neoliberal urban practices combined with the promotion of conservative political agendas. The reason there is lacking discussion on opposition towards the project of hosting the Olympic Games is that there is not a thorough public debate on the topic. In other words, the Olympics do not make it to the higher ranks of public agenda, except for the three-week period they are held in. In this sense, a sheer indifference ${ }^{31}$ towards the potential of hosting the Olympics Games can be observed and the limited debate surrounding it can be categorized as an island of agreement in favour, among social classes of different political affiliations. However, international sports events are an integral part of the policy of establishing and propagating a novel national identity for the AKP. Taking advantage of the neoliberal processes that are at play in the transformation of the urban environment, the construction sector in Turkey immensely grew during this period and consequently took a central role in the increasing number of bids for hosting international sports events. While İstanbul's bid for hosting the 2020 Summer Olympics is a failed one, it requires attention due to the frame it draws for the aforementioned policy and the city's key position as the formative space of the reimagining of national identity by the conservative-Islamist politics in Turkey.

FUNDING: This research received no external funding.

CONFLICT OF INTEREST: The author declares no conflict of interest.

\footnotetext{
${ }^{31}$ A study by Çoknaz et al. (2010) demonstrate that nearly \%46 of physical education and sports students at higher education level do not know which city filed its candidacy for hosting the Olympics.
} 


\section{REFERENCES}

Allison, Lincoln \& Terry Monnington. 2002. "Sport, Prestige and International Relations." Government and Opposition 37(1):106-34. doi: 10.1111/1477-7053.00089

Amnesty International. 2019. Reality Check: The State of Migrant Workers' Rights with Four Years to Go Until the Qatar 2022 World Cup. MDE 22/9758/2019. London.

Balaban, Osman. 2016. “İnşaat Sektörü Neyin Lokomotifi?” Pp. 17-32 in İnşaat Ya Resulullah, edited by T. Bora. İstanbul: Birikim.

Batuman, Bülent. 2019. Milletin Mimarisi: Yeni İslamcı Ulus İnşasının Kent ve Mekan Siyaseti. İstanbul: Metis.

Bilsel, Cânâ, and Halûk Zelef. 2011. "Mega Events in Istanbul from Henri Prost's Master Plan of 1937 to the Twenty-First-Century Olympic Bids.” Planning Perspectives 26(4): 621-34. doi: 10.1080/02665433.2011.599931

Black, David. 2007. "The Symbolic Politics of Sport Mega-Events: 2010 in Comparative Perspective." Politikon 34(3): 261-76. doi: 10.1080/02589340801962536

Bora, Tanıl. 2000. “Fatih'in İstanbul'u: Siyasal İslam'ın Alternatif Küresel Şehir” Hayalleri.” Pp. 60-77 in İstanbul: Küresel ile Yerel Arasında, edited by Ç. Keyder. İstanbul: Metis.

Bora, Tanıl. 2016. “Türk Muhafazakarlığı ve İnşaat Şehveti: Büyük Olsun Bizim Olsun.” Pp. 9-15 in İnşaat Ya Resulullah, edited by T. Bora. İstanbul: Birikim.

Boykoff, Jules. 2016. Power Games: The Political History of the Olympic Games. London: Verso.

Brown, Wendy. 2003. "Neo-Liberalism and the End of Liberal Democracy.” Theory \& Event 7(1). doi: 10.1353/tae.2003.0020

Bruff, Ian. 2014. “The Rise of Authoritarian Neoliberalism.” Rethinking Marxism 26(1): 113-29. doi: 10.1080/08935696.2013.843250

Çavdar, Ayşe. 2016. "Building, Marketing and Living in an Islamic Gated Community: Novel Configurations of Class and Religion in Istanbul.” International Journal of Urban and Regional Research 40(3): 507-23. doi: https://doi.org/10.1111/14682427.12364

Çavuşoğlu, Erbatur \& Julia Strutz. 2014. "Producing Force and Consent: Urban Transformation and Corporatism in Turkey." City 18(2): 134-48. doi: 10.1080/13604813.2014.896643

Chalkley, Brian \& Stephen Essex. 1999. "Urban Development through Hosting International Events: A History of the Olympic Games.” Planning Perspectives 14(4): 369-94. doi: 10.1080/026654399364184

Çoknaz, Dilşad, Meliha Atalay Noordegraaf, Lale Güler, \& Müfide Yoruç Çotuk. 2010. “Beden Eğitimi ve Spor Yüksekokulu Öğrencilerinin Olimpik Konulara Yönelik Farkındalıkları ve Olimpik Kavramlara Ilişkin Değerlendirmeleri.” Uluslararası Insan Bilimleri Dergisi 7(1): 1264-1289.

Edelman, Murray. 1967. The Symbolic Uses of Politics. London: University of Illinois Press.

Giulianotti, Richard, Gary Armstrong, Gavin Hales, \& Dick Hobbs. 2015. “Sport Mega-Events and Public Opposition: A Sociological Study of the Lon- 
don 2012 Olympics.” Journal of Sport and Social Issues 39(2): 99-119. doi: $10.1177 / 0193723514530565$

Grix, Jonathan \& Donna Lee. 2013. “Soft Power, Sports Mega-Events and Emerging States: The Lure of the Politics of Attraction." Global Society 27(4): 521-36. doi: 10.1080/13600826.2013.827632

Harvey, David. 1989. "From Managerialism to Entrepreneurialism: The Transformation in Urban Governance in Late Capitalism.” Geografiska Annaler: Series B, Human Geography 71(1): 3-17. doi: 10.1080/04353684.1989.11879583

Hiller, Harry H. 1999. “Toward an Urban Sociology of Mega-Events. Pp. 181-205 in Constructions of Urban Space. Vol. 5, Research in Urban Sociology, edited by R. Hutchison. Bradford: Emerald Group Publishing Limited.

Horne, John \& Wolfram Manzenreiter. 2006. “An Introduction to the Sociology of Sports Mega-Events.” The Sociological Review 54(2): 1-24. doi: 10.1111/j.1467954X.2006.00650.x

Jessop, Bob. 2002. "Liberalism, Neoliberalism, and Urban Governance: A State-Theoretical Perspective." Antipode 34(3): 452-72. doi: https://doi.org/10.1111/14678330.00250

Keyder, Çağlar. 2000. “Arka Plan.” Pp. 9-40 in İstanbul: Küresel ile Yerel Arasında. İstanbul: Metis.

Lauermann, John. 2016. “Temporary Projects, Durable Outcomes: Urban Development through Failed Olympic Bids?” Urban Studies 53(9): 1885-1901. doi: 10.1177/0042098015585460

Lefebvre, Henri. 1991. The Production of Space. Oxford, UK \& Cambridge, USA: Blackwell.

Leitner, Helga \& Mark Garner. 1993. “The Limits of Local Initiatives: A Reassessment of Urban Entrepreneurialism for Urban Development.” Urban Geography 14(1): 57-77. doi: 10.2747/0272-3638.14.1.57

McManus, John. 2018. Welcome to Hell? In Search of the Real Turkish Football. London: Weidenfeld \& Nicolson.

Peck, Jamie, Nik Theodore, \& Neil Brenner. 2009. “Neoliberal Urbanism: Models, Moments, Mutations.” SAIS Review of International Affairs 29(1):49-66. doi: 10.1353/ sais. 0.0028

Skey, Michael. 2006. "Carnivals of Surplus Emotion? Towards an Understanding of the Significance of Ecstatic Nationalism in a Globalising World.” Studies in Ethnicity and Nationalism 6(2): 143-61. doi: https://doi.org/10.1111/j.1754-9469.2006. tb00154.x

Swyngedouw, Erik Achille. 1992. "The Mammon Quest. Glocalisation, Interspatial Competition and the New Monetary Order: The Construction of New Scales.” Pp. 39-67 in Cities and Regions in the New Europe, edited by M. Dunford \& Kaflakas Grigoris. London: Belhaven.

Tokdoğan, Nagehan. 2018. Yeni Osmanlıcılık: Hınç, Nostalji, Narsisizm. İstanbul: İletişim.

Tomlinson, Alan \& Christopher Young, eds. 2006. National Identity and Global Sports Events: Culture, Politics and Spectactle in the Olympics and the Football World Cup. 
Albany: State University of New York Press.

Vincent, John, John S. Hill, Andrew Billings, John Harris, \& C. Dwayne Massey. 2018.

"We Are GREAT Britain: British Newspaper Narratives during the London 2012

Olympic Games.” International Review for the Sociology of Sport 53(8): 895-923. doi: 10.1177/1012690217690345

Yeşilbağ, Melih. 2016. “Hegemonyanın Harcı: AKP Döneminde İnşaata Dayalı Birikim Rejimi.” SBF Dergisi 71(2): 599-626.

\section{BIOGRAPHICAL NOTE}

Yavuz Yavuz is a researcher at the Sociology Department of Ankara University in Turkey. His research interests include sociology of sport, nationalism theories and urban sociology.

OPEN ACCESS: This article is distributed under the terms of the Creative Commons Attribution Non-commercial License (CC BY-NC 4.0) which permits any non-commercial use, and reproduction in any medium, provided the original author(s) and source are credited. 